\title{
The CIC-3 chloride channels in cardiovascular disease
}

\author{
Dayue Darrel DUAN* \\ Laboratory of Cardiovascular Phenomics, Center of Biomedical Research Excellence, Department of Pharmacology, University of \\ Nevada School of Medicine, Reno, NV 89557, USA
}

CIC-3 is a member of the $\mathrm{CIC}$ voltage-gated chloride $(\mathrm{Cl})$ channel superfamily. Recent studies have demonstrated the abundant expression and pleiotropy of CIC-3 in cardiac atrial and ventricular myocytes, vascular smooth muscle cells, and endothelial cells. CIC-3 $\mathrm{Cl}^{-}$channels can be activated by increase in cell volume, direct stretch of $\beta 1$-integrin through focal adhesion kinase and many active molecules or growth factors including angiotensin II and endothelin-1-mediated signaling pathways, $\mathrm{Ca}^{2+} / \mathrm{calmodulin}^{-\mathrm{dependent}}$ protein kinase II and reactive oxygen species. CIC-3 may function as a key component of the volume-regulated $\mathrm{Cl}^{-}$channels, a superoxide anion transport and/or NADPH oxidase interaction partner, and a regulator of many other transporters. CIC-3 has been implicated in the regulation of electrical activity, cell volume, proliferation, differentiation, migration, apoptosis and intracellular $\mathrm{pH}$. This review will highlight the major findings and recent advances in the study of $\mathrm{ClC}-3 \mathrm{Cl}^{-}$channels in the cardiovascular system and discuss their important roles in cardiac and vascular remodeling during hypertension, myocardial hypertrophy, ischemia/reperfusion, and heart failure.

Keywords: CIC; chloride channels; heart disease; apoptosis; oxidative stress; remodeling; hypertension

Acta Pharmacologica Sinica (2011) 32: 675-684; doi: 10.1038/aps.2011.30; published online 23 May 2011

\section{Introduction}

ClC-3 is a member of the $\mathrm{ClC}$ voltage-gated chloride $\left(\mathrm{Cl}^{-}\right)$ channel gene superfamily ${ }^{[1]}$. In 1994, ClC-3 cDNA was first cloned from rat kidney by Kawasaki et al using a polymerase chain reaction $(\mathrm{PCR})$ cloning strategy ${ }^{[2]}$. ClC-3 is also abundantly expressed in brain ${ }^{[3]}$, lung, kidney ${ }^{[4]}$, heart ${ }^{[5,6]}$, and vasculature $^{[7]}$ of many species, including human ${ }^{[4,6,8]}$. Expression of the cloned rat ClC-3 yielded an outwardly-rectifying $\mathrm{Cl}^{-}$ current in Xenopus oocytes ${ }^{[2]}$ and in somatic cell lines ${ }^{[3]}$, which was completely inhibited by activation of protein kinase $\mathrm{C}$ $(\mathrm{PKC})^{[2]}$ or increased intracellular $\mathrm{Ca}^{2+}$ concentration ${ }^{[3]}$. The $\mathrm{Cl}^{-}$currents produced by expression of cardiac $\mathrm{ClC}-3$ in mammalian cells are also outwardly-rectifying and inhibited by PKC and share many biophysical and pharmacological characteristics with the volume-regulated $\mathrm{Cl}^{-}$currents $\left(I_{\mathrm{Cl} \text {, vol }}\right)$ in cardiac myocytes ${ }^{[5,9,10-13]}$, vascular smooth muscle cells ${ }^{[7]}$, and many other cell types ${ }^{[14-16]}$. ClC-3 $\mathrm{Cl}^{-}$channels can be activated also by direct stretch of $\beta 1$-integrin through focal adhesion kinase and many active molecules or growth factors including angiotensin II (Ang II) and endothelin-1 mediated

\footnotetext{
* To whom correspondence should be addressed.

E-mail dduan@medicine.nevada.edu

Received 2011-02-16 Accepted 2011-03-14
}

signaling pathways ${ }^{[17-20]}, \mathrm{Ca}^{2+} /$ calmodulin-dependent protein kinase II $(\mathrm{CaMKII})^{[21]}$ and reactive oxygen species ${ }^{[22,23]}$. In the past 15 years, accumulated experimental data has shown that ClC-3 proteins are expressed in sarcolemmal membranes and intracellular organelles of cardiac myocytes, vascular smooth muscle cells, and endothelial cells ${ }^{[24-27]}$. Numerous studies have demonstrated the pleiotropy of ClC-3 in many cellular functions, including 1) as a key component of the volumeregulated $\mathrm{Cl}^{-}$channels (VRCCs) to strengthen the regulatory volume decrease (RVD) and protect cardiac myocytes from excessive increase in cell volume during hypoxia, ischemia, or hypertrophy; 2) as a regulator of the redox signaling pathway through interaction with NADPH oxidase (Nox) and/or as a superoxide anion $\left(\mathrm{O}_{2}{ }^{--}\right)$transporter to improve myocyte viability against oxidative damage; 3 ) as an anti-apoptotic mechanism through regulation of cell volume and intracellular $\mathrm{pH}$; and 4) as a regulator of other transport functions involved in the etiology of myocardial damage, heart failure, and hypertension (Figure 1).

This review will highlight the major findings and recent advances in the study of $\mathrm{ClC}-3 \mathrm{Cl}^{-}$channels in the cardiovascular system and discuss their important roles in cardiac and vascular remodeling during hypertension, myocardial ischemia/reperfusion, hypertrophy, and heart failure. 


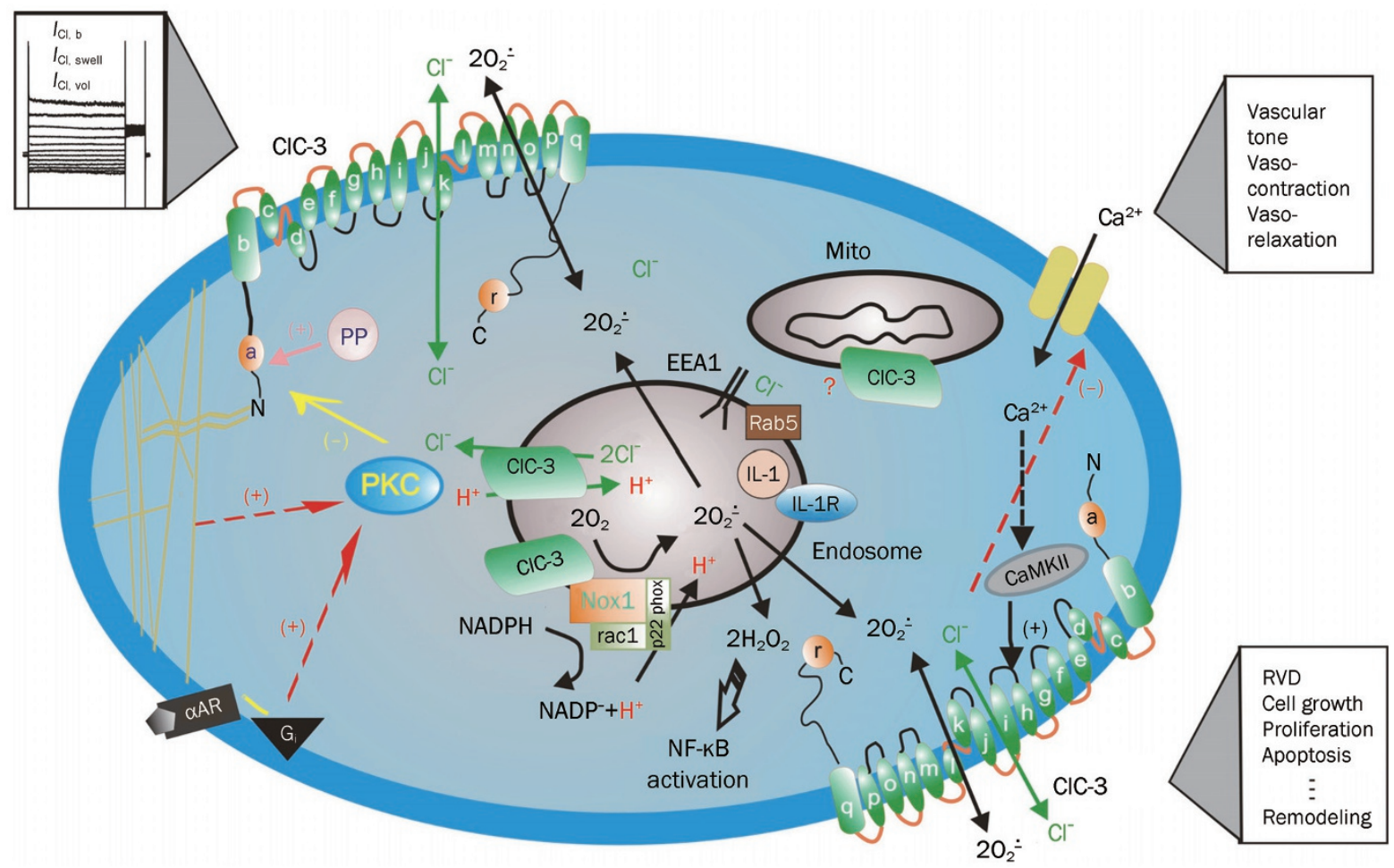

Figure 1. Schematic representation of regulation and function of $\mathrm{ClC}_{-3} \mathrm{Cl}^{-}$channels in cardiac myocytes and vascular smooth muscle cells. ClC-3, a member of voltage-gated $\mathrm{ClC} \mathrm{Cl}^{-}$channel family, encodes $\mathrm{Cl}^{-}$channels in cardiac myocytes and vascular smooth muscle cells that are volume regulated $\left(I_{\mathrm{Cl}, \text { vol }}\right)$ and can be activated by cell swelling $\left(I_{\mathrm{Cl}, \text { swell }}\right)$ induced by exposure to hypotonic extracellular solutions or possibly membrane stretch. $I_{\mathrm{Cl}, \mathrm{b}}$ is a basally activated $\mathrm{ClC}-3 \mathrm{Cl}^{-}$current. Membrane topology model ( $\alpha$-helices a- $r$ ) for $\mathrm{ClC}-3$ is modified from Dutzler et al ${ }^{[100]}$. ClC-3 proteins are expressed on both sarcolemmal membrane and intracellular organelles including mitochondria (mito) and endosomes. The proposed model of endosome ion flux and function of Nox 1 and CIC-3 in the signaling endosome is modified from Miller Jr et al ${ }^{[101]}$. Binding of IL-1 $1 \beta$ or TNF- $\alpha$ to the cell membrane initiates endocytosis and formation of an early endosome (EEA1 and Rab5), which also contains NADPH oxidase subunits Nox1 and p22phox, in addition to CIC-3. Nox1 is electrogenic, moving electrons from intracellular NADPH through a redox chain within the enzyme into the endosome to reduce oxygen to superoxide. CIC-3 functions as a chloride-proton exchanger, required for charge neutralization of the electron flow generated by Nox1. The ROS generated by Nox1 result in NF-KB activation. Both ClC-3 and Nox1 are necessary for generation of endosomal ROS and subsequent NF-kB activation by IL-1 $\beta$ or TNF- $\alpha$ in VSMCs. PKC, protein kinase C; PP, serine-threonine protein phosphatases; $\alpha$-AR, $\alpha$-adrenergic receptor; $G_{i}$, heterodimeric inhibitory G protein; Nox: NADPH oxidase; CaMKII: $\mathrm{Ca}^{2+} /$ calmodulin-dependent protein kinase II; (+) stimulation; (-) inhibition.

\section{CIC-3 and VRCCs}

Under osmotic, metabolic, and/or oxidative stress mammalian cells are able to precisely maintain their size through the regulated loss or gain of intracellular ions or other osmolytes to avoid excessive alterations of cell volume that may jeopardize structural integrity and a variety of cellular functions ${ }^{[28-31]}$. Even under physiological conditions, volume constancy of any mammalian cell is challenged by the transport of osmotically active substances across the cell membrane and alterations in cellular osmolarity by metabolism ${ }^{[28]}$. Thus, the continued operation of cell volume regulatory mechanisms, such as activation of VRCCs, is required for cell volume homeostasis in many mammalian cells, including cardiac myocytes and vascular smooth muscle cells (VSMCs) $)^{[2,24,32,33]}$. Acute increase in cell volume (or cell swelling) initiates the regulatory volume decrease (RVD) process to bring the cells back to their initial volume, which is achieved by the opening of VRCCs and other channels and transporters mediating $\mathrm{Cl}^{-}$,
$\mathrm{K}^{+}$, and taurine efflux that in turn drives water exit ${ }^{[28]}$.

Although the exact identification of the protein(s) responsible for VRCCs has proven to be elusive, ClC-3 has been proposed to be the molecular correlate of the native VRCCs in cardiac myocytes ${ }^{[5]}$ and VSMCs ${ }^{[7]}$. But the role of $\mathrm{ClC}-3$ as a constituent of native VRCCs became an issue of debate owing to inconsistent and conflicting data collected from some laboratories $^{[34-36]}$. Specially, the presence of the native VRCCs in two different cell types from the global $\mathrm{ClC}-3$ knockout $\left(\mathrm{Clcn}^{-/-}\right)$ mice $^{[35]}$ casts considerable doubt on the role of $\mathrm{ClC}-3$ as a molecular component of VRCCs. However, later additional experiments using $\mathrm{Clcn}^{-/-}$mice revealed that the properties of native VRCCs in the $\mathrm{Clcn3}^{-/-}$heart were significantly altered and the expression of a variety of membrane proteins other than $\mathrm{ClC}-3$ was also markedly changed, raising fundamental questions about the usefulness of the $\mathrm{Clnn}^{-/-}$mouse model to assess ClC-3 function ${ }^{[37]}$. A series of recent independent studies from many laboratories further strongly corroborated the 
hypothesis that $\mathrm{ClC}-3$ encoded a key component of the native VRCCs in a variety cell types ranging from normal cardiac myocytes to cancer cells ${ }^{[16,20,37-46]}$. Knockdown of ClC-3 by $\operatorname{siRNA}^{[41,42,47]}$, shRNA ${ }^{[48,49]}$, and antisense ${ }^{[20,39,43,45]}$ and intracellular dialysis of anti-ClC-3 antibody $(\mathrm{Ab})^{[16,37,38,44-46]}$ all consistently eliminated VRCC currents in many types of cells. A recent study using the inducible heart-specific $\mathrm{ClC}-3$ knockout mouse found that a time-dependent inactivation of $\mathrm{ClC}-3$ gene expression was correlated with an elimination of the endogenous VRCCs (Figure 2) and significantly compromised cardiac function (Figure 2) ${ }^{[50]}$. Therefore, $\mathrm{ClC}-3$ remains a strong and viable candidate for VRCCs in the heart and may contribute to normal cardiac function.

\section{VRCCs and CIC-3 in cardioprotection induced by ischemic preconditioning (IPC)}

Ischemic preconditioning (IPC) is a phenomenon in which brief episodes of ischemia dramatically reduce myocardial infarction caused by a subsequent sustained ischemia ${ }^{[51]}$. IPC has an early phase (lasting 1-2 h) and a late phase or "second window" (lasting 24-72 h) of protection ${ }^{[52]}$. It has been reported that the block of $I_{\mathrm{Cl} \text {, swell }}$ in rabbit cardiac myocytes inhibits IPC by brief ischemia, hypo-osmotic stress ${ }^{[53,54]}$ and adenosine receptor agonists ${ }^{[55]}$. These studies were solely based on the use of several $\mathrm{Cl}^{-}$channel blockers, such as anthracene-9-carboxylic acid (9-AC) and 4-acetamide-4'isothiocyanatostilbene-2,2'-disulfonic acid (SITS). These pharmacological tools lack specificity to a particular $\mathrm{Cl}^{-}$ channel in the heart and may also act on other ion channels or transporters ${ }^{[56,57]}$. Therefore the causal role of $I_{\mathrm{Cl} \text {, swell }}$ in IPC has been very difficult to be confirmed ${ }^{[58]}$. To specifically test whether the VRCCs are indeed involved in IPC, we have recently established in vitro and in vivo models of early IPC and late IPC in $\mathrm{ClCn}^{-/-}$mice. Our preliminary results indicate that targeted inactivation of $\mathrm{ClC}-3$ gene prevented protective effects of late IPC but not of early IPC, suggesting that ClC-3/VRCCs may contribute differently to early and late IPC ${ }^{[59,60]}$. The underlying mechanisms for these differential effects are currently unknown. Recent reports, however, suggest that VRCCs and ClC-3 may play an important role in apoptosis $^{[61]}$ and inflammation ${ }^{[62]} \cdot \mathrm{Cl}^{-}$channel blockers DIDS and NPPB were as potent as a broad-spectrum caspase inhibitor in preventing apoptosis and elevation of caspase- 3 activity and improved cardiac contractile function after ischemia and in vivo reperfusion ${ }^{[63]}$. Transgenic mice overexpressing Bcl-2 in the heart had significantly smaller infarct size and reduced apoptosis of myocytes after ischemia and reperfusion ${ }^{[64]}$. It has been shown that $\mathrm{Bcl}-2$ induces up-regulation of $I_{\mathrm{Cl}}$, vol by enhancing $\mathrm{ClC}-3$ expression in human prostate cancer epithelial cells ${ }^{[65]}$. Cell shrinkage is an integral part of apoptosis, suggesting that $I_{\mathrm{Cl}, \text { vol }}$ and $\mathrm{ClC}-3$ might be intimately linked to apoptotic events through regulation of cell volume homeosta$\operatorname{sis}^{[61,65,66]}$.

\section{VRCCs and CIC-3 in myocardial hypertrophy and heart failure}

Structural remodeling of myocardial hypertrophy and dilated cardiomyopathy involves oxidative stress and hypertrophic cell volume increase or dilated myocyte membrane stretch, which alters cell volume homeostasis and many cellular functions including cell proliferation, differentiation, and apoptosis. $I_{\mathrm{Cl} \text {, swell }}$ is persistently activated in ventricular myocytes from a canine pacing-induced dilated cardiomyopathy mode ${ }^{[67]}$. Using the perforated patch-clamp technique, Clemo et al found that, even in isotonic solutions, a large 9-AC-sensitive, outwardly rectifying $\mathrm{Cl}^{-}$current was recorded in failing cardiac myocytes but not in normal cardiac myocytes. Graded hypotonic cell swelling (60\%-90\% hypotonic) failed to activate additional current while graded hypertonic cell shrinkage caused an inhibition of the "basal" $\mathrm{Cl}^{-}$current in failing myocytes. Moreover, the maximum current density of the $I_{\mathrm{Cl}}$, swell in failing myocytes was about $40 \%$ greater than that in osmotically swollen normal myocytes. Constitutive activation of $I_{\mathrm{Cl} \text {, swell }}$ is also observed in several other animal models of heart failure, such as a rabbit aortic regurgitation model of dilated cardiomyopathy ${ }^{[68]}$, a dog model of heart failure caused by myocardial infarction ${ }^{[69]}$, and a mouse model of myocardial hypertrophy by aorta binding ${ }^{[70]}$. In human atrial myocytes obtained from patients with right atrial enlargement and/or elevated left ventricular end-diastolic pressure, a tamoxifen sensitive $I_{\mathrm{Cl}}$, swell was also found to be persistently activated ${ }^{[67]}$. Therefore, it is possible that persistent activation of $I_{\mathrm{Cl} \text {, swell }}$ is a common response of cardiac myocytes to hypertrophy or heart failure-induced remodeling.

The mechanism for persistent activation of $I_{\mathrm{Cl} \text {, swell }}$ in hypertrophied or failing cardiac myocytes is still not clear. Perhaps the increase in cell volume caused by hypertrophy and the stretch of cell membrane caused by dilation are both involved

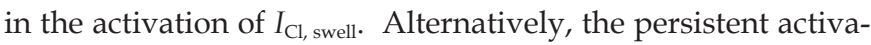
tion of $I_{\mathrm{Cl} \text {, swell }}$ may be caused by signaling cascades activated during hypertrophy independent of changes in cell length and volume, or both. $I_{\mathrm{Cl} \text {, swell }}$ could be activated by direct stretch of $\beta 1$-integrin through focal adhesion kinase (FAK) and/or $\mathrm{Src}^{[49]}$. Mechanical stretch of myocytes also releases Ang II, which binds to AT1 receptors (AT1R) and stimulates FAK and Src in an autocrine-paracrine loop. A recent study by Browe and Baumgarten suggests that the stretch of $\beta 1$-integrin in cardiac myocytes activates $I_{\mathrm{Cl} \text {, swell }}$ by activating AT1R and NADPH oxidase and, thereby, producing reactive oxygen species (ROS). In addition, a potent NADPH oxidase inhibitor, diphenyleneiodonium (DPI), and a structurally unrelated NADPH oxidase inhibitor, 4-(2-aminoethyl) benzenesulfonyl fluoride (AEBSF), rapidly and completely blocked both background and stretch-activated $\mathrm{Cl}^{-}$currents in cardiac myocytes ${ }^{[19]}$. Therefore, NADPH oxidase may be intimately coupled to the channel responsible for $I_{\mathrm{Cl}}$, vol, providing a second regulatory pathway for this channel through membrane stretch or oxidative stress ${ }^{[19]}$. This finding is very important for further understanding of the mechanism for hypertrophy activa- 
A a on Doxy

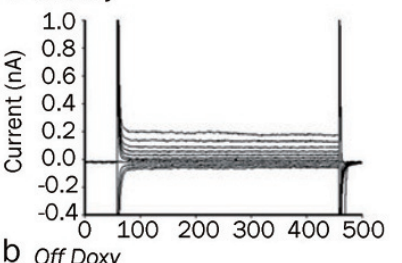

Off Doxy

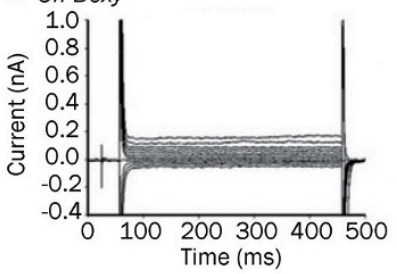

B a On Doxy
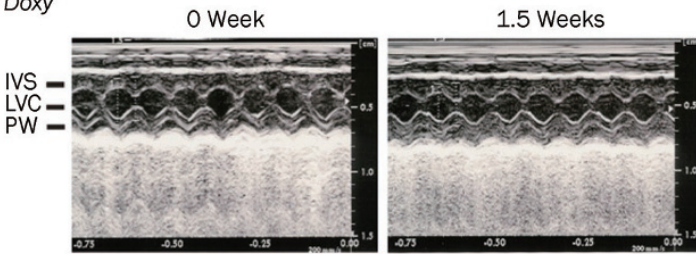

b Off Doxy
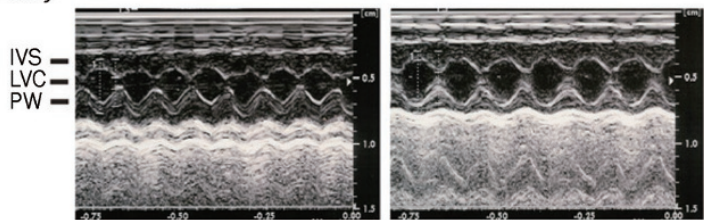

C

\begin{tabular}{|c|c|c|c|c|c|c|}
\hline & \multicolumn{2}{|c|}{0 week } & \multicolumn{2}{|c|}{1.5 weeks } & \multicolumn{2}{|c|}{3 weeks } \\
\hline & $\begin{array}{c}\text { On Doxy } \\
n=8\end{array}$ & $\begin{array}{c}\text { Off Doxy } \\
n=15\end{array}$ & $\begin{array}{c}\text { On Doxy } \\
n=4\end{array}$ & $\begin{array}{c}\text { Off Doxy } \\
n=12\end{array}$ & $\begin{array}{c}\text { On Doxy } \\
n=5\end{array}$ & $\begin{array}{c}\text { Off Doxy } \\
n=9\end{array}$ \\
\hline IVSs (mm) & $1.64 \pm 0.05$ & $1.61 \pm 0.03$ & $1.60 \pm 0.07$ & $1.49 \pm 0.04^{*}$ & $1.61 \pm 0.05$ & $1.48 \pm 0.04^{*}$ \\
\hline LVIDs (mm) & $0.95 \pm 0.11$ & $0.98 \pm 0.08$ & $1.02 \pm 0.15$ & $1.51 \pm 0.09^{* * *, \#}$ & $1.01 \pm 0.11$ & $1.57 \pm 0.10^{* * *, \# \#}$ \\
\hline LVPWs (mm) & $1.41 \pm 0.07$ & $1.45 \pm 0.05$ & $1.18 \pm 0.10$ & $1.33 \pm 0.06$ & $1.35 \pm 0.08$ & $1.31 \pm 0.07$ \\
\hline Systole Area $\left(\mathrm{mm}^{2}\right)$ & $2.61 \pm 0.52$ & $2.93 \pm 0.38$ & $1.89 \pm 0.73$ & $3.77 \pm 0.42$ & $2.41 \pm 0.55$ & $3.16 \pm 0.49$ \\
\hline IVSd (mm) & $0.81 \pm 0.02$ & $0.81 \pm 0.02$ & $0.76 \pm 0.03$ & $0.76 \pm 0.02$ & $0.80 \pm 0.02$ & $0.80 \pm 0.02$ \\
\hline LVIDd (mm) & $2.86 \pm 0.12$ & $2.94 \pm 0.08$ & $2.81 \pm 0.16$ & $3.26 \pm 0.09^{*, \#}$ & $2.94 \pm 0.12$ & $3.21 \pm 0.11$ \\
\hline LVPWd (mm) & $1.08 \pm 0.05$ & $1.08 \pm 0.04$ & $1.02 \pm 0.07$ & $1.08 \pm 0.04$ & $0.98 \pm 0.05$ & $1.07 \pm 0.05$ \\
\hline Diastole Area $\left(\mathrm{mm}^{2}\right)$ & $11.36 \pm 1.29$ & $13.26 \pm 0.94$ & $13.83 \pm 1.83$ & $14.44 \pm 1.05$ & $12.07 \pm 1.38$ & $12.09 \pm 1.22$ \\
\hline FS (\%) & $66.88 \pm 2.12$ & $67.08 \pm 1.55$ & $63.65 \pm 3.00$ & $54.36 \pm 1.73^{* * *, \#}$ & $65.35 \pm 2.27$ & $51.62 \pm 2.00^{* * *, \#}$ \\
\hline LVEF (\%) & $79.01 \pm 2.16$ & $78.11 \pm 1.58$ & $85.21 \pm 3.06$ & $74.25 \pm 1.76^{\# \#}$ & $80.02 \pm 2.31$ & $75.20 \pm 2.04$ \\
\hline $\operatorname{Mass}\left(\mathrm{mg} / \mathrm{mm}^{2}\right)$ & $89.06 \pm 4.36$ & $92.33 \pm 3.18$ & $78.65 \pm 6.16$ & $103.08 \pm 3.56^{* * *, \# \#}$ & $83.93 \pm 4.66$ & $102.02 \pm 4.11^{* * *, \#}$ \\
\hline Body Weight (g) & $34.86 \pm 2.55$ & $43.10 \pm 1.86^{\#}$ & $33.15 \pm 3.61$ & $41.21 \pm 2.08$ & $35.04 \pm 2.73$ & $36.34 \pm 2.40$ \\
\hline Mass/BW Ratio & $2.69 \pm 0.18$ & $2.17 \pm 0.13$ & $2.37 \pm 0.26$ & $2.55 \pm 0.15^{*}$ & $2.38 \pm 0.12$ & $2.86 \pm 0.17^{* * *, \#}$ \\
\hline
\end{tabular}

${ }^{*} P<0.05,{ }^{* *} P<0.01,{ }^{* * *} P<0.001$ vs off Doxy 0 week; ${ }^{\#} P<0.05,{ }^{\# \#} P<0.01$, ${ }^{\# \# \#} P<0.001$ vs on Doxy at the same time point.

D

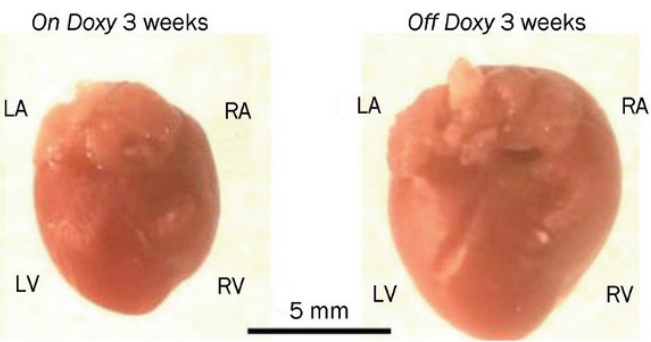

C

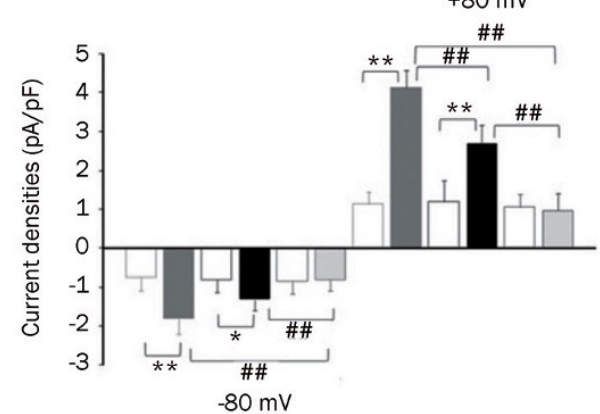

3 Weeks

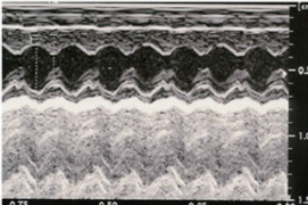

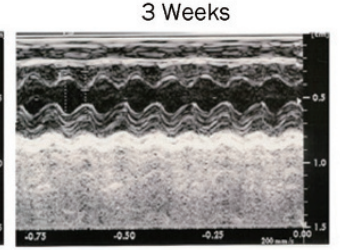
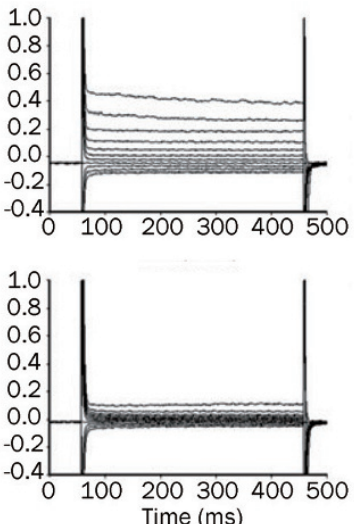
tion of $I_{\mathrm{Cl} \text {, swell }}$ and $\mathrm{ClC}-3$ channels and their relationship with hypertrophy and heart failure as it is very well known that Ang II plays a crucial role in myocardial hypertrophy and heart failure ${ }^{[71]}$. Interestingly, Miller and colleagues recently found that $\mathrm{Cl}^{-}$channel inhibitors and knockout of $\mathrm{ClC}-3$ abolished cytokine-induced generation of ROS in endosomes and ROS-dependent NF-kB activation in vascular smooth muscle cells ${ }^{[37]}$, suggesting a potential close interaction between NADPH oxidase and ClC-3 (Figure 1). In human corneal keratocytes and human fetal lung fibroblasts $\mathrm{ClC}-3$ knockdown by a short hairpin RNA (shRNA) significantly decreased VRCC and lysophosphatidic acid (LPA)-activated $\mathrm{Cl}^{-}$current $\left(I_{\mathrm{Cl}, \mathrm{LPA}}\right)$ in the presence of transforming growth factor- $\beta 1$ (TGF- $\beta 1$ ) compared with controls, whereas ClC-3 overexpression resulted in increased $I_{\mathrm{Cl}, \mathrm{LPA}}$ in the absence of TGF- $\beta 1^{[72]}$. ClC-3 knockdown also resulted in a reduction of a-smooth muscle actin (a-SMA) protein levels in the presence of TGF$\beta 1$, whereas $\mathrm{ClC}-3$ overexpression increased a-SMA protein expression in the absence of TGF- $\beta 1$. In addition, keratocytes transfected with $\mathrm{ClC}-3$ shRNA had a significantly blunted regulatory volume decrease response following hyposmotic stimulation compared with controls. These data not only confirm that $\mathrm{ClC}-3$ is important in VRCC function and cell volume regulation, but also provides new insight into the mechanism for the ClC-3-mediated fibroblast-to-myofibroblast transition $^{[15]}$.

The functional and clinical significance of VRCCs in the hypertrophied and dilated heart is currently unknown. Using a mouse aortic binding model of myocardial hypertrophy, we have found that globally targeted disruption of $\mathrm{ClC}-3$ gene $\left(\mathrm{ClCn}^{-/-}\right)$accelerated the development of myocardial hypertrophy and the discompensatory process, suggesting that activation of $I_{\mathrm{Cl} \text {, vol }}$ might be important in the adaptive remodeling of the heart during pressure overload ${ }^{[73]}$. Interestingly, heart failure was found to be accompanied by a reduced $I_{\mathrm{Cl} \text {, vol }}$ density in rabbit cardiac myocytes ${ }^{[43]}$. Our recent studies on the conditional heart-specific ClC-3 knockout $\left(\mathrm{hsClcn3}^{-/-}\right)$ mice (Figure 3) support the crucial functional role of $\mathrm{ClC}-3$ channels in the adaptive remodeling of the heart against pressure overload $^{[72]}$. As shown in Figure 3, echocardiography revealed marked signs of myocardial hypertrophy (a significant increase in left ventricular mass LVM) and heart failure (a significant increase in LVIDs and reduction in IVSs, LVEF, and $\% \mathrm{FS}$ ) in the $\mathrm{hsClcn}^{-/-}$mice compared to their age-matched wild-type control mice (Figure 3B). In addition, both left and right atria were significantly enlarged (Figure $3 \mathrm{C}$ ). These data strongly suggest that $\mathrm{ClC}-3$ may play an important role in maintaining normal structure and function of the mammalian heart.

\section{VRCCs and CIC-3 in electrophysiology and electrical remodeling}

Activation of VRCCs is expected to produce depolarization of the resting membrane potential and significant shortening of action potential duration (APD) because of its strong outwardly rectifying property ${ }^{[5,11,24,74,75]}$. The $\mathrm{Cl}^{-}$current through

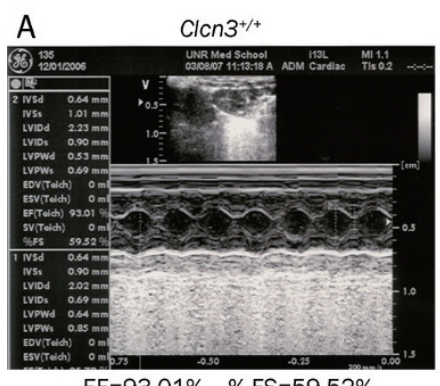

$\mathrm{EF}=93.01 \% \quad \% \mathrm{FS}=59.52 \%$

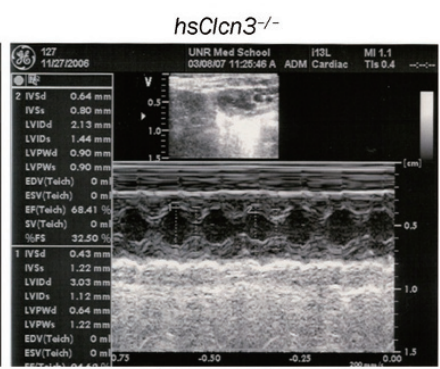

$\mathrm{EF}=63.41 \% \quad \% \mathrm{FS}=35.50 \%$
B

\begin{tabular}{lcc}
\hline & Clcn3 $^{+/+}(n=8)$ & hsClcn3 \\
\hline IVSd (mm) & & \\
IVSs (mm) & $0.54 \pm 0.02$ & $0.56 \pm 0.02$ \\
IVIDd (mm) & $1.31 \pm 0.09$ & $1.01 \pm 0.04^{*}$ \\
LVIDs (mm) & $2.63 \pm 0.16$ & $2.69 \pm 0.09$ \\
LVPWd (mm) & $0.84 \pm 0.07$ & $1.52 \pm 0.09^{* * *}$ \\
LVPWs (mm) & $0.74 \pm 0.05$ & $0.81 \pm 0.05$ \\
LVEF & $1.22 \pm 0.05$ & $1.23 \pm 0.05$ \\
$\%$ FS & $0.97 \pm 0.04$ & $0.80 \pm 0.03^{* * *}$ \\
HR (bpm) & $67.05 \pm 3.57$ & $43.88 \pm 2.85^{* * *}$ \\
LVM (mg) & $495.71 \pm 22.58$ & $396.13 \pm 19.11^{* *}$ \\
\hline
\end{tabular}

${ }^{*} P<0.05,{ }^{* *} P<0.01,{ }^{* * *} P<0.001$ vs $\mathrm{Clcn}^{+/+}$.
C

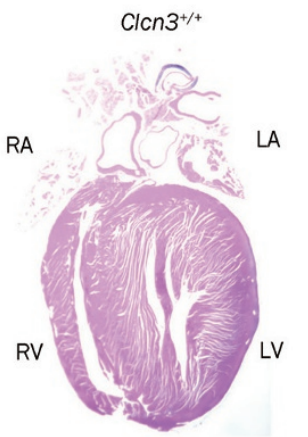

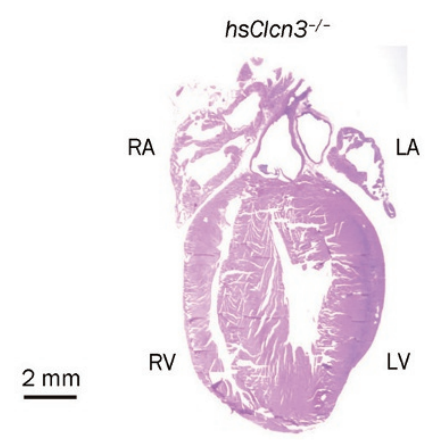

Figure 3. Echocardiography of cardiac function of wild type and heartspecific CIC-3 knockout mice. (A) Representative M-mode echocardiography from wild-type $\left(\mathrm{Clcn} 3^{+/+}\right.$; left) and heart-specific ClC-3 knockout (hsClcn3 $3^{-/-}$; right) mice. (B) Echocardiographic measurements in $\mathrm{Clcn3}^{+/+}$ and $\mathrm{hsClcn3}^{-/-}$mice. IVSd, interventricular septum thickness at the end of diastole; LVIDd, left ventricular (LV) dimension at the end of diastole; LVPWd, LV posterior wall thickness at the end of diastole; IVSs, interventricular septum thickness at the end of systole; LVIDs, LV dimension at the end of systole; LVPWs, LV posterior wall thickness at the end of systole; LVEP, calculated LV ejection fraction; \%FS, LV fractional shortening; Estimated LV mass, LVM $(\mathrm{mg})=1.05\left[(I V S+L V I D+L V P W)^{3}-(\text { LVID })^{3}\right]$, where 1.05 is the specific gravity of the myocardium. (C) Single longitudinal section (8 $\mu \mathrm{m})$ of hearts to demonstrate all four heart chambers. Longitudinal were stained with hematoxylin and eosin $(B a r=2 \mathrm{~mm})$ (Ye L and Duan DD. unpublished data).

the VRCCs under basal or isotonic conditions is small ${ }^{[10,11,76]}$ but can be further activated by stretching of the cell mem- 
brane by inflation ${ }^{[77]}$ or direct mechanical stretch of membrane $\beta_{1}$-integrin ${ }^{[78]}$ and/or cell swelling induced by exposure to hypoosmotic solutions ${ }^{[5,9-13]}$. The consequences of activation of $I_{\mathrm{C} \text {, vol }}$ are very complex. It may be detrimental, beneficial, or both simultaneous in different parts of the heart, depending on environmental influences.

Because cardiac myocytes swell during hypoxia and ischemia, and the washout of hyperosmotic extracellular fluid after reperfusion induces further cell swelling, activation of VRCCs may contribute to APD shortening and arrhythmias induced by hypoxia, ischemia and reperfusion ${ }^{[79]}$. Shortening of APD and, therefore, the effective refractory period (ERP) reduces the length of the conducting pathway needed to sustain reentry (wavelength). In principle, this favors the development of atrial fibrillation (AF) or ventricular fibrillation $(\mathrm{VF})$, depending on the presence of multiple reentrant circuits or rotating spiral waves. Activation of $I_{\mathrm{Cl} \text {, vol }}$ may slow or enhance the conduction of early extrasystoles, depending on the timing. In guinea-pig heart, hypo-osmotic solution shortened APD and increased APD gradients between right and left ventricles. In burst stimulation-induced VF, exposure to hypo-osmotic solution increased VF frequencies, transforming complex fast Fourier transformation spectra to a single dominant high frequency on the left but not the right ventricle ${ }^{[19]}$. Perfusion with the VRCC blocker indanyloxyacetic acid-94 reversed organized VF to complex VF with lower frequencies, indicating that VRCC underlies the changes in VF dynamics. Consistent with this interpretation, $\mathrm{ClC}-3$ channel protein expression is $27 \%$ greater on left than right ventricles, and computer simulations showed that insertion of $I_{\mathrm{Cl} \text {, vol }}$ transformed complex VF to a stable spiral. Therefore, activation of $I_{\mathrm{Cl} \text {, vol }}$ has a major impact on VF dynamics by transforming random multiple wavelets to a highly organized VF with a single dominant frequency.

In the case of myocardial hypertrophy and heart failure, ionic remodeling is one of the major features of pathophysiological changes ${ }^{[80]}$. Under these conditions, $I_{\mathrm{Cl} \text {, vol }}$ is constitutively active ${ }^{[69]}$. The persistent activation of $I_{\mathrm{Cl}, \mathrm{vol}}$ may limit the APD prolongation and make it more difficult to elicit early after depolarization (EAD). Indeed, in myocytes from failing hearts, blocking $I_{\mathrm{Cl} \text {, vol }}$ by tamoxifen significantly prolonged APD and decreased the depolarizing current required to elicit EAD by about $50 \%$. And hyper-osmotic cell shrinkage,

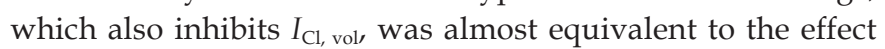
of tamoxifen on APD and EAD in these myocytes ${ }^{[79]}$. It has been shown that mechanical stretching or dilation of the atrial myocardium is able to cause arrhythmias. Since $I_{\mathrm{Cl} \text {, vol }}$ was also found in sino-atrial (S-A) nodal cells, VRCCs may serve as a mediator of mechanotransduction and play a significant role in the pacemaker function if they act as the stretch-activated channels in these cells ${ }^{[79,81]}$. Baumgarten's laboratory has recently demonstrated that $I_{\mathrm{Cl} \text {, vol }}$ in ventricular myocytes can be directly activated by mechanical stretch through selectively stretching $\beta_{1}$-integrins with $\mathrm{mAb}$-coated magnetic beads ${ }^{[19,79]}$. Although it has been suggested that stretch and swelling activate the same anion channel in some non-cardiac cells, further study is needed to determine whether this is true in cardiac myocytes and VSMCs.

\section{VRCC and CIC-3 in vasculature and hypertensive vascular remodeling}

It has been demonstrated that VRCCs and $\mathrm{ClC}-3$ are expressed in aortic and pulmonary VSMCs of human and several other speicies $^{[20,82,83]}$ and have been implicated in a number of vital cellular functions including vascular myogenic tone, cell volume regulation, cell proliferation and apoptosis ${ }^{[7,26,61,84]}$.

Membrane stretch or increases in transmural pressure cause contraction of vascular smooth muscle cells, ie, myogenic response ${ }^{[85]}$. Early studies revealed that the myogenic response was associated with membrane depolarization ${ }^{[86]}$. Ion channels sensitive to mechanical stimuli have been suggested to serve as the sensor element of the myogenic response of vascular smooth muscle. Mechano-sensitive $\mathrm{Cl}^{-}$channels and VRCCs have been observed in vascular smooth muscle cells ${ }^{[7,87]}$ and a pressure-induced $\mathrm{Cl}^{-}$efflux was reported ${ }^{[88]}$. Activation of VRCCs and ClC-3 has been postulated to participate in the myogenic response $\mathrm{e}^{[7,84,86,87]}$, such as in the membrane depolarization and contraction mediated by activation of $a_{1}$-adrenoceptors and vascular wall distension due to increased transmural pressure ${ }^{[89]}$. However, convincing functional evidence for the functional role of VRCCs or $\mathrm{ClC}-3$ in myogenic response and myogenic tone is still lacking due to the lack of specific $\mathrm{Cl}^{-}$channel blockers ${ }^{[90]}$. Further study using the $\mathrm{ClC}-3$ knockout or transgenic mice may provide more insights into the functional role of $\mathrm{ClC}-3$ and VRCCs in the regulation of myogenic response to mechanical stretch.

Arterial VSMC proliferation is a key event in the development of hypertension-associated vascular disease ${ }^{[83]}$. Recent accumulating evidence suggests an important role of $\mathrm{ClC}-3$ and VRCCs in the regulation of cell proliferation induced by numerous mitogenic factors ${ }^{[61]}$. The magnitude of VRCC currents in actively growing VSMCs is higher than in growtharrested or differentiated VSMCs, suggesting that VRCCs may be important for VSMC proliferation ${ }^{[91]}$. Antisense oligonucleotide-mediated downregulation of ClC-3 dramatically inhibits cell proliferation of rat aortic VSMCs ${ }^{[20]}$. A recent study found that static pressure increased VRCCs and $\mathrm{ClC}-3$ expression and promoted rat aortic VSMC proliferation and cell cycle progression $^{[83]}$. Inhibition of VRCCs with pharmacological blockers (such as DIDS or the NADPH oxidase inhibitor DPI) or knockdown of $\mathrm{ClC}-3$ with $\mathrm{ClC}-3$ antisense oligonucleotide transfection attenuated pressure evoked cell proliferation and cell cycle progression. Static pressure enhanced the production of ROS in aortic smooth muscle cells. DPI or apocynin pretreatment inhibited pressure-induced ROS production as well as cell proliferation. Furthermore, DPI or apocynin attenuated the pressure-induced upregulation of $\mathrm{ClC}-3$ protein and VRCC current. These data suggest that VRCCs may play a critical role in static pressure-induced cell proliferation and cell cycle progression. Therefore, VRCCs may be of unique therapeutic importance for treatment of hypertension attendant vascular complications. 
Cerebral resistance arteries undergo remodeling of the vascular walls during chronic hypertension, which is caused by the coordination of vascular smooth muscle cell proliferation and migration, endothelial cell dysfunction, inflammation and fibrosis. A very recent study demonstrated that the expression of ClC-3 and VRCC activity were increased in basilar artery during hypertension and simvastatin, an inhibitor of 3-hydroxy-3-methylglutaryl coenzyme A (HMG-CoA) reductase widely used in clinics for the treatment of hypercholesterolemia, normalized the upregualtion of $\mathrm{ClC}-3^{[92]}$. Furthermore, simvastatin ameliorated hypertension-caused cerebrovascular remodeling through inhibition of VRCCs and ClC-3 and cell proliferation $^{[92]}$. These effects of simvastatin were abolished by pretreatment with mevalonate or geranylgeranyl pyrophosphate. In addition, Rho A inhibitor C3 exoenzyme and Rho kinase inhibitor Y-27632 both reduced cell proliferation and activation of VRCCs. ClC-3 overexpression decreased the suppressive effect of simvastatin on endothelin-1 and hypoosmolarity-induced cell proliferation. These results provided novel mechanistic insight into the beneficial effects of statins in the treatment of hypertension and stroke through an inhibition of ClC-3 and VRCC function.

\section{CIC-3 and superoxide transport and interaction with NADPH oxidase}

ROS has been implicated in cellular signaling processes as well as a cause of oxidative stress-induced cell proliferation ${ }^{[93]}$. One of the major sources of ROS in the heart and vasculature is through one or more isoforms of the phagocytic enzyme NADPH oxidase, a membrane-localized protein which generates the superoxide $\left(\mathrm{O}_{2}{ }^{--}\right)$anion on the extracellular surface of the plasma membrane (Figure 1). As a charged and short lived anion, it is believed that $\mathrm{O}_{2}{ }^{\cdot-}$ flux is insufficient to initiate intracellular signaling due to the combination of poor permeability through the phospholipid bilayer ${ }^{[94]}$ and a rapid dismutation to its uncharged and more stable derivative, hydrogen peroxide $^{[95,96]}$. However, recent evidence has indicated discrete signaling roles for both $\mathrm{O}_{2}$ and $\mathrm{H}_{2} \mathrm{O}_{2}{ }^{[97]}$.

In response to monocrotaline-induced pulmonary hypertension the expression of $\mathrm{ClCn} 3$ gene was upregulated in rat pulmonary artery ${ }^{[98]}$. In canine cultured pulmonary arterial smooth muscle cells (PASMCs) incubated with inflammatory mediators Clcn3 gene was also upregulated ${ }^{[98]}$. Overexpression of ClC-3 in PASMCs enhanced viability of the cells against $\mathrm{H}_{2} \mathrm{O}_{2}$, thus suggesting that $\mathrm{ClC}-3$ may improve the resistance of VSMCs to ROS in an environment of elevated inflammatory cytokines in hypertensive pulmonary arteries ${ }^{[98]}$. It was found that extracellular $\mathrm{O}_{2}{ }^{--}$, but not $\mathrm{H}_{2} \mathrm{O}_{2}$, led to $\mathrm{Ca}^{2+}$ signaling and apoptosis in pulmonary endothelial cells ${ }^{[99]}$. This indicates that extracellular $\mathrm{O}_{2}{ }^{\cdot-}$ produced by NADPH oxidase or other sources either crosses the plasma membrane or modifies cell surface proteins to mediate cell signaling (Figure 1).

Recently, Hawkins et al studied the transmembrane flux of $\mathrm{O}_{2}{ }^{--}$in pulmonary microvascular endothelial cells ${ }^{[17]}$. Application of an extracellularbolus of $\mathrm{O}_{2}{ }^{--}$resulted in rapid and concentration-dependent transient $\mathrm{O}_{2}{ }^{--}$-sensitive fluorophore hydroethidine (HE) oxidation that was followed by a progressive and nonreversible increase in nuclear HE fluorescence. These fluorescence changes were inhibited by superoxide dismutase (SOD), and the $\mathrm{Cl}^{-}$channel blocker DIDS, and selective silencing of $\mathrm{ClC}-3$ by treatment with siRNA. Extracellular $\mathrm{O}_{2}{ }^{--}$triggered $\mathrm{Ca}^{2+}$ release, in turn triggered mitochondrial membrane potential alterations that were followed by mitochondrial $\mathrm{O}_{2}{ }^{--}$production and cellular apoptosis. These "signaling" effects of $\mathrm{O}_{2}{ }^{--}$were prevented by DIDS, by depletion of intracellular $\mathrm{Ca}^{2+}$ stores with thapsigargin and by chelation of intracellular $\mathrm{Ca}^{2+}$. This study demonstrates that $\mathrm{O}_{2}{ }^{--}$flux across the endothelial cell plasma membrane occurs through ClC-3 channels and induces intracellular $\mathrm{Ca}^{2+}$ release, which activates mitochondrial $\mathrm{O}_{2}{ }^{--}$generation. These and other studies suggest that activation of $\mathrm{ClC}-3$ may indeed play a role in cell proliferation, growth, volume regulation and apoptosis of VSMCs.

\section{Conclusion}

Regulation of $\mathrm{ClC}-3$ functions in the cardiovascular system is emerging as a novel and important mechanism for the electrical and structural remodeling of the heart and vasculature. However, the integrated function of $\mathrm{ClC}-3$ as a key component of VRCC and Nox1 and as a transport of superoxide needs to be further explored. Although specific gene targeting and transgenic approaches have been proven very powerful for specifically addressing the questions, it will be ideal if specific compounds for $\mathrm{ClC}-3$ can be developed as pharmacological tools to answer these questions and to develop drugs targeting $\mathrm{ClC}-3$ as novel therapeutic tools for the treatment of many cardiac and vascular diseases such as myocardial hypertrophy, ischemia, heart failure, and hypertension.

\section{Acknowledgements}

The research is supported by grants from the National Institutes of Health (HL63914 and HL106256), National Center of Research Resources (NCRR, P20RR15581), and American Diabetes Association Innovation Award (\#07-8-IN-08).

\section{References}

1 Jentsch TJ. CLC chloride channels and transporters: from genes to protein structure, pathology and physiology. Crit Rev Biochem Mol Biol 2008; 43: 3-36.

2 Kawasaki M, Suzuki M, Uchida S, Sasaki S, Marumo F. Stable and functional expression of the CIC-3 chloride channel in somatic cell lines. Neuron 1995; 14: 1285-91.

3 Kawasaki M, Uchida S, Monkawa T, Miyawaki A, Mikoshiba K, Marumo F, et al. Cloning and expression of a protein kinase C-regulated chloride channel abundantly expressed in rat brain neuronal cells. Neuron 1994; 12: 597-604.

4 Sasaki S, Uchida S, Kawasaki M, Adachi S, Marumo F. CIC family in the kidney. Jpn J Physiol 1994; 44: S3-8.

5 Duan D, Winter C, Cowley S, Hume JR, Horowitz B. Molecular identification of a volume-regulated chloride channel. Nature 1997; 390: 417-21.

6 Britton FC, Hatton WJ, Rossow CF, Duan D, Hume JR, Horowitz B. Molecular distribution of volume-regulated chloride channels (CIC-2 
and CIC-3) in cardiac tissues. Am J Physiol Heart Circ Physiol 2000; 279: H2225-33.

7 Yamazaki J, Duan D, Janiak R, Kuenzli K, Horowitz B, Hume JR. Functional and molecular expression of volume-regulated chloride channels in canine vascular smooth muscle cells. J Physiol (Lond) 1998; 507: 729-36.

8 Borsani G, Rugarli El, Taglialatela M, Wong C, Ballabio A. Characterization of a human and murine gene (CLCN3) sharing similarities to voltage-gated chloride channels and to a yeast integral membrane protein. Genomics 1995; 27: 131-41.

9 Du XY, Sorota S. Cardiac swelling-induced chloride current depolarizes canine atrial myocytes. Am J Physiol 1997; 272: H190416.

10 Duan D, Fermini B, Nattel S. Alpha-adrenergic control of volumeregulated $\mathrm{Cl}^{-}$currents in rabbit atrial myocytes. Characterization of a novel ionic regulatory mechanism. Circ Res 1995; 77: 379-93.

11 Duan D, Hume JR, Nattel S. Evidence that outwardly rectifying $\mathrm{Cl}^{-}$ channels underlie volume-regulated $\mathrm{Cl}^{-}$currents in heart. Circ Res 1997; 80: 103-13.

12 Duan D, Cowley S, Horowitz B, Hume JR. A serine residue in CIC3 links phosphorylation-dephosphorylation to chloride channel regulation by cell volume. J Gen Physiol 1999; 113: 57-70.

13 Sorota S. Swelling-induced chloride-sensitive current in canine atrial cells revealed by whole-cell patch-clamp method. Circ Res 1992; 70: 679-87.

14 Dick GM, Bradley KK, Horowitz B, Hume JR, Sanders KM. Functional and molecular identification of a novel chloride conductance in canine colonic smooth muscle. Am J Physiol Cell Physiol 1998; 275: c940-50.

15 Hermoso M, Satterwhite CM, Andrade YN, Hidalgo J, Wilson SM, Horowitz B, et al. CIC-3 is a fundamental molecular component of volume-sensitive outwardly rectifying $\mathrm{Cl}^{-}$channels and volume regulation in HeLa cells and Xenopus laevis oocytes. J Biol Chem 2002; 277: 40066-74.

16 Wang GX, Hatton WJ, Wang GL, Zhong J, Yamboliev I, Duan D, et al. Functional effects of novel anti-CIC-3 antibodies on native volumesensitive osmolyte and anion channels in cardiac and smooth muscle cells. Am J Physiol Heart Circ Physiol 2003; 285: H1453-63.

17 Hawkins BJ, Madesh M, Kirkpatrick CJ, Fisher AB. Superoxide flux in endothelial cells via the chloride channel-3 mediates intracellular signaling. Mol Biol Cell 2007; 18: 2002-12.

18 Hiramatsu M, Furukawa T, Sawanobori T, Hiraoka M. Ion channel remodeling in cardiac hypertrophy is prevented by blood pressure reduction without affecting heart weight increase in rats with abdominal aortic banding. J Cardiovasc Pharmacol 2002; 39: 866 74.

19 Browe DM, Baumgarten CM. Angiotensin II (AT1) receptors and NADPH oxidase regulate $\mathrm{Cl}^{-}$current elicited by \{beta\}1 integrin stretch in rabbit ventricular myocytes. J Gen Physiol 2004; 124: 273-87.

20 Wang GL, Wang XR, Lin MJ, He H, Lan XJ, Guan YY. Deficiency in CIC-3 chloride channels prevents rat aortic smooth muscle cell proliferation. Circ Res 2002; 91: E28-E32

21 Huang P, Liu J, Di A, Robinson NC, Musch MW, Kaetzel MA, et al. Regulation of human CLC-3 channels by multifunctional $\mathrm{Ca}^{2+} /$ calmodulin-dependent protein kinase. J Biol Chem 2001; 276: 20093-100.

22 Browe DM, Baumgarten CM. EGFR kinase regulates volume-sensitive chloride current elicited by integrin stretch via PI-3K and NADPH oxidase in ventricular myocytes. J Gen Physiol 2006; 127: 237-51.

23 Matsuda JJ, Filali MS, Moreland JG, Miller FJ, Lamb FS. Activation of swelling-activated chloride current by tumor necrosis factor-alpha requires $\mathrm{CIC}$-3-dependent endosomal reactive oxygen production. J Biol Chem 2010; 285: 22864-73.

24 Duan D. Phenomics of cardiac chloride channels: the systematic study of chloride channel function in the heart. J Physiol (Lond) 2009; 587: 2163-77.

25 Duan DY, Liu LL, Bozeat N, Huang ZM, Xiang SY, Wang GL, et al. Functional role of anion channels in cardiac diseases. Acta Pharmacol Sin 2005; 26: 265-78.

26 Hume JR, Duan D, Collier ML, Yamazaki J, Horowitz B. Anion transport in heart. Physiol Rev 2000; 80: 31-81.

27 Hume JR, Wang GX, Yamazaki J, Ng LC, Duan D. CLC-3 chloride channels in the pulmonary vasculature. Adv Exp Med Biol 2010; 661: 237-47.

28 Hoffmann EK, Lambert IH, Pedersen SF. Physiology of cell volume regulation in vertebrates. Physiol Rev 2009; 89: 193-277.

29 Lang F. Mechanisms and significance of cell volume regulation. J Am Coll Nutr 2007; 26: 613S-623S.

30 Strange K. Cellular volume homeostasis. Adv Physiol Educ 2004; 28: 155-9.

31 Cala PM, Maldonado $\mathrm{H}$, Anderson SE. Cell volume and $\mathrm{pH}$ regulation by the Amphiuma red blood cell: a model for hypoxia-induced cell injury. Comp Biochem Physiol Comp Physiol 1992; 102: 603-8.

32 Xiong D, Wang GX, Burkin DJ, Yamboliev IA, Singer CA, Rawat S, et al. Cardiac-specific overexpression of the human short CLC-3 chloride channel isoform in mice. Clin Exp Pharmacol Physiol 2009; 36: 386-93.

33 Zhang J, Lieberman M. Chloride conductance is activated by membrane distention of cultured chick heart cells. Cardiovasc Res 1996; 32: 168-79.

34 Li X, Shimada K, Showalter LA, Weinman SA. Biophysical properties of CIC-3 differentiate it from swelling-activated chloride channels in Chinese hamster ovary-K1 cells. J Biol Chem 2000; 275: 35994-8.

35 Stobrawa SM, Breiderhoff T, Takamori S, Engel D, Schweizer M, Zdebik AA, et al. Disruption of CIC-3, a chloride channel expressed on synaptic vesicles, leads to a loss of the hippocampus. Neuron 2001; 29: 185-96.

36 Weylandt KH, Valverde MA, Nobles M, Raguz S, Amey JS, Diaz M, et al. Human $\mathrm{CIC}-3$ is not the swelling-activated chloride channel involved in cell volume regulation. J Biol Chem 2001; 276: 17461-7.

37 Yamamoto-Mizuma S, Wang GX, Liu LL, Schegg K, Hatton WJ, Duan $D$, et al. Altered properties of volume-sensitive osmolyte and anion channels (VSOACs) and membrane protein expression in cardiac and smooth muscle myocytes from $\mathrm{Clcn3}^{-/-}$mice. J Physiol (Lond) 2004; 557: 439-56.

38 Duan D, Zhong J, Hermoso M, Satterwhite CM, Rossow CF, Hatton WJ, et al. Functional inhibition of native volume-sensitive outwardly rectifying anion channels in muscle cells and Xenopus oocytes by anti-CIC-3 antibody. J Physiol (Lond) 2001; 531: 437-44.

39 Vessey JP, Shi C, Jollimore CA, Stevens KT, Coca-Prados M, Barnes S, et al. Hyposmotic activation of $I_{\mathrm{Cl}, \text { swell }}$ in rabbit nonpigmented ciliary epithelial cells involves increased $\mathrm{CIC}-3$ trafficking to the plasma membrane. Biochem Cell Biol 2004; 82: 708-18.

40 Tang YB, Zhou JG, Guan YY. Volume-regulated chloride channels and cerebral vascular remodelling. Clin Exp Pharmacol Physiol 2010; 37: $238-42$.

41 Tang YB, Liu YJ, Zhou JG, Wang GL, Qiu QY, Guan YY. Silence of CIC3 chloride channel inhibits cell proliferation and the cell cycle via G/ $\mathrm{S}$ phase arrest in rat basilar arterial smooth muscle cells. Cell Prolif 2008; 41: 775-85.

42 Tao R, Lau CP, Tse HF, Li GR. Regulation of cell proliferation by intermediate-conductance $\mathrm{Ca}^{2+}$-activated potassium and volume- 
sensitive chloride channels in mouse mesenchymal stem cells. Am $J$ Physiol Cell Physiol 2008; 295: C1409-16.

43 Mao J, Chen L, Xu B, Wang L, Li H, Guo J, et al. Suppression of CIC-3 channel expression reduces migration of nasopharyngeal carcinoma cells. Biochem Pharmacol 2008; 75: 1706-16.

44 Do CW, Lu W, Mitchell CH, Civan MM. Inhibition of swelling-activated $\mathrm{Cl}^{-}$currents by functional anti-ClC-3 antibody in native bovine nonpigmented ciliary epithelial cells. Invest Ophthalmol Vis Sci 2005; 46: 948-55.

45 Zhou JG, Ren JL, Qiu QY, He H, Guan YY. Regulation of intracellular $\mathrm{Cl}^{-}$concentration through volume-regulated $\mathrm{CIC}-3$ chloride channels in A10 vascular smooth muscle cells. J Biol Chem 2005; 280: 7301-8.

46 Jin NG, Kim JK, Yang DK, Cho SJ, Kim JM, Koh EJ, et al. Fundamental role of $\mathrm{ClC}-3$ in volume-sensitive $\mathrm{Cl}^{-}$channel function and cell volume regulation in AGS cells. Am J Physiol Gastrointest Liver Physiol 2003; 285: G938-48.

47 Tao R, Lau CP, Tse HF, Li GR. Functional ion channels in mouse bone marrow mesenchymal stem cells. Am J Physiol Cell Physiol 2007; 293: C1561-7.

48 Cuddapah VA, Sontheimer H. Molecular interaction and functional regulation of $\mathrm{ClC}-3$ by $\mathrm{Ca}^{2+} /$ calmodulin-dependent protein kinase II (CaMKII) in human malignant glioma. J Biol Chem 2010; 285 : 11188-96

49 Yin Z, Tong Y, Zhu H, Watsky MA. CIC-3 is required for LPA-activated $\mathrm{Cl}^{-}$current activity and fibroblast-to-myofibroblast differentiation. Am J Physiol Cell Physiol 2008; 294: C535-42

50 Xiong D, Heyman NS, Airey J, Zhang M, Singer CA, Rawat S, et al. Cardiac-specific, inducible $\mathrm{CIC}-3$ gene deletion eliminates native volume-sensitive chloride channels and produces myocardial hypertrophy in adult mice. J Mol Cell Cardiol 2010; 48: 211-9.

51 Murry CE, Jennings RB, Reimer KA. Preconditioning with ischemia: a delay of lethal cell injury in ischemic myocardium. Circulation 1986; 74: 1124-36.

52 Guo Y, Wu WJ, Qiu Y, Tang XL, Yang Z, Bolli R. Demonstration of an early and a late phase of ischemic preconditioning in mice. Am J Physiol Heart Circ Physiol 1998; 275: H1375-87

53 Diaz RJ, Losito VA, Mao GD, Ford MK, Backx PH, Wilson GJ. Chloride channel inhibition blocks the protection of ischemic preconditioning and hypo-osmotic stress in rabbit ventricular myocardium. Circ Res 1999; 84: 763-75.

54 Diaz RJ, Batthish M, Backx PH, Wilson GJ. Chloride channel inhibition does block the protection of ischemic preconditioning in myocardium. J Mol Cell Cardiol 2001; 33: 1887-9.

55 Batthish M, Diaz RJ, Zeng HP, Backx PH, Wilson GJ. Pharmacological preconditioning in rabbit myocardium is blocked by chloride channel inhibition. Cardiovasc Res 2002; 55: 660-71.

56 Heusch G, Liu GS, Rose J, Cohen MV, Downey JM. No confirmation for a causal role of volume-regulated chloride channels in ischemic preconditioning in rabbits. J Mol Cell Cardiol 2000; 32: 2279-85.

57 Sorota S. Pharmacologic properties of the swelling-induced chloride current of dog atrial myocytes. J Cardiovasc Electrophysiol 1994; 5: 1006-16.

58 Heusch G, Cohen MV, Downey JM. Ischemic preconditioning through opening of swelling-activated chloride channels? Circ Res 2001; 89: E48.

59 Bozeat N, Dwyer L, Ye L, Yao T, Duan D. The role of CIC-3 chloride channels in early and late ischemic preconditioning in mouse heart. FASEB J 2005; 19: A694-5.

60 Bozeat N, Dwyer L, Ye L, Yao TY, Hatton WJ, Duan D. VSOACs play an important cardioprotective role in late ischemic preconditioning in mouse heart. Circulation 2006; 114: 272-3.

61 Guan YY, Wang GL, Zhou JG. The CIC-3 $\mathrm{Cl}^{-}$channel in cell volume regulation, proliferation and apoptosis in vascular smooth muscle cells. Trends Pharmacol Sci 2006; 27: 290-6.

62 Volk AP, Heise CK, Hougen JL, Artman CM, Volk KA, Wessels D, et al. CIC-3 and $I_{\text {Cl-swell }}$ are required for normal neutrophil chemotaxis and shape change. J Biol Chem 2008; 283: 34315-26.

63 Mizoguchi K, Maeta H, Yamamoto A, Oe M, Kosaka H. Amelioration of myocardial global ischemia/reperfusion injury with volumeregulatory chloride channel inhibitors in vivo. Transplantation 2002; 73: 1185-93.

64 Chen Z, Chua CC, Ho YS, Hamdy RC, Chua BH. Overexpression of $\mathrm{Bcl}-2$ attenuates apoptosis and protects against myocardial $\mathrm{I} / \mathrm{R}$ injury in transgenic mice. Am J Physiol Heart Circ Physiol 2001; 280: H2313-20.

65 Lemonnier L, Shuba Y, Crepin A, Roudbaraki M, Slomianny C, Mauroy $\mathrm{B}$, et al. Bcl-2-dependent modulation of swelling-activated $\mathrm{Cl}^{-}$current and $\mathrm{CIC}-3$ expression in human prostate cancer epithelial cells. Cancer Res 2004; 64: 4841-8.

66 Wei L, Xiao AY, Jin C, Yang A, Lu ZY, Yu SP. Effects of chloride and potassium channel blockers on apoptotic cell shrinkage and apoptosis in cortical neurons. Pflugers Arch 2004; 448: 325-34.

67 Patel DG, Higgins RS, Baumgarten CM. Swelling-activated $\mathrm{Cl}$ current, $I_{\mathrm{Cl} \text {, swell, }}$ is chronically activated in diseased human atrial myocytes. Biophys J 2003; 84: 233a.

68 Clemo HF, Baumgarten CM. Protein kinase $\mathrm{C}$ activation blocks $I_{\mathrm{Cl}(\text { swell })}$ and causes myocyte swelling in a rabbit congestive heart failure model. Circulation 1998; 98: I-695.

69 Clemo HF, Stambler BS, Baumgarten CM. Swelling-activated chloride current is persistently activated in ventricular myocytes from dogs with tachycardia-induced congestive heart failure. Circ Res 1999; 84: 157-65.

70 Duan D, Liu L, Wang GL, Ye L, Tian H, Yao Y, et al. Cell volumeregulated ion channels and ionic remodeling in hypertrophied mouse heart. J Cardiac Failure 2004; 10: S72.

71 van Borren MM, Verkerk AO, Vanharanta SK, Baartscheer A, Coronel $\mathrm{R}$, Ravesloot JH. Reduced swelling-activated $\mathrm{Cl}^{-}$current densities in hypertrophied ventricular myocytes of rabbits with heart failure. Cardiovasc Res 2002; 53: 869-78.

72 Xiong D, Ye L, Neveux I, Burkin DJ, Scowen P, Evans R, et al. Cardiac specific inactivation of $\mathrm{CIC}-3$ gene reveals cardiac hypertrophy and compromised heart function. FASEB J 2008; 22: 970.25.

73 Liu LH, Ye L, McGuckin C, Hatton WJ, Duan D. Disruption of Clcn3 gene in mice facilitates heart failure during pressure overload. J Gen Physiol 2003; 122: 33A.

74 Hiraoka M, Kawano S, Hirano Y, Furukawa T. Role of cardiac chloride currents in changes in action potential characteristics and arrhythmias. Cardiovas Res 1998; 40: 23-33.

75 Vandenberg JI, Bett GC, Powell T. Contribution of a swelling-activated chloride current to changes in the cardiac action potential. Am J Physiol 1997; 273: C541-7.

76 Duan D, Fermini B, Nattel S. Sustained outward current observed after $I_{\text {to1 }}$ inactivation in rabbit atrial myocytes is a novel $\mathrm{Cl}^{-}$current. Am J Physiol 1992; 263: H1967-71.

77 Du XY, Sorota S. Modulation of dog atrial swelling-induced chloride current by cAMP: protein kinase A-dependent and -independent pathways. J Physiol (Lond) 1997; 500: 111-22.

78 Browe DM, Baumgarten CM. Stretch of beta 1 integrin activates an outwardly rectifying chloride current via $\mathrm{FAK}$ and $\mathrm{Src}$ in rabbit ventricular myocytes. J Gen Physiol 2003; 122: 689-702

79 Baumgarten CM, Clemo HF. Swelling-activated chloride channels in 
cardiac physiology and pathophysiology. Prog Biophys Mol Biol 2003; 82: $25-42$

80 Tomaselli GF, Marban E. Electrophysiological remodeling in hypertrophy and heart failure. Cardiovasc Res 1999; 42: 270-83.

81 Hagiwara N, Masuda H, Shoda M, Irisawa H. Stretch-activated anion currents of rabbit cardiac myocytes. J Physiol (Lond) 1992; 456: 285-302.

82 Lamb FS, Clayton GH, Liu BX, Smith RL, Barna TJ, Schutte BC. Expression of CLCN voltage-gated chloride channel genes in human blood vessels. J Mol Cell Cardiol 1999; 31: 657-66.

83 Qian JS, Pang RP, Zhu KS, Liu DY, Li ZR, Deng CY, et al. Static pressure promotes rat aortic smooth muscle cell proliferation via upregulation of volume-regulated chloride channel. Cell Physiol Biochem 2009; 24: 461-70.

84 Nelson MT. Bayliss, myogenic tone and volume-regulated chloride channels in arterial smooth muscle. J Physiol (Lond) 1998; 507: 629.

85 Meininger GA, Davis MJ. Cellular mechanisms involved in the vascular myogenic response. Am J Physiol Heart Circ Physiol 1992; 263: H647-H659.

86 Jackson WF. Ion channels and vascular tone. Hypertension 2000; 35: $173-8$.

87 Nelson MT, Conway MA, Knot HJ, Brayden JE. Chloride channel blockers inhibit myogenic tone in rat cerebral arteries. J Physiol (Lond) 1997; 502: 259-64.

88 Doughty JM, Langton PD. Measurement of chloride flux associated with the myogenic response in rat cerebral arteries. J Physiol (Lond) 2001; 534: 753-61.

89 Remillard CV, Lupien MA, Crepeau V, Leblanc N. Role of $\mathrm{Ca}^{2+}$ - and swelling-activated $\mathrm{Cl}^{-}$channels in alpha1-adrenoceptor-mediated tone in pressurized rabbit mesenteric arterioles. Cardiovasc Res 2000; 46: 557-68.

90 Doughty JM, Miller AL, Langton PD. Non-specificity of chloride channel blockers in rat cerebral arteries: block of the L-type calcium channel. J Physiol (Lond) 1998; 507: 433-9.
91 Voets T, Wei L, De SP, Van DW, Eggermont J, Droogmans G, et al. Downregulation of volume-activated $\mathrm{Cl}^{-}$currents during muscle differentiation. Am J Physiol Cell Physiol 1997; 272: C667-74.

92 Liu YJ, Wang XG, Tang YB, Chen JH, Lv XF, Zhou JG, et al. Simvastatin ameliorates rat cerebrovascular remodeling during hypertension via inhibition of volume-regulated chloride channel. Hypertension 2010; 56: 445-52.

93 Taniyama Y, Griendling KK. Reactive oxygen species in the vasculature: molecular and cellular mechanisms. Hypertension 2003; 42: 1075-81.

94 Tanabe S, Wang X, Takahashi N, Uramoto H, Okada Y. $\mathrm{HCO}_{3}(-)-$ independent rescue from apoptosis by stilbene derivatives in rat cardiomyocytes. FEBS Lett 2005; 579: 517-22.

95 Finkel T. Oxidant signals and oxidative stress. Curr Opin Cell Biol 2003; 15: 247-54.

96 Finkel T, Deng CX, Mostoslavsky R. Recent progress in the biology and physiology of sirtuins. Nature 2009; 460: 587-91.

97 Devadas S, Zaritskaya L, Rhee SG, Oberley L, Williams MS. Discrete generation of superoxide and hydrogen peroxide by $T$ cell receptor stimulation: selective regulation of mitogen-activated protein kinase activation and fas ligand expression. J Exp Med 2002; 195: 59-70.

98 Dai YP, Bongalon S, Hatton WJ, Hume JR, Yamboliev IA. CIC-3 chloride channel is upregulated by hypertrophy and inflammation in rat and canine pulmonary artery. Br J Pharmacol 2005; 145: 5-14.

99 Madesh M, Hawkins BJ, Milovanova T, Bhanumathy CD, Joseph SK, Ramachandrarao SP, et al. Selective role for superoxide in InsP3 receptor-mediated mitochondrial dysfunction and endothelial apoptosis. J Cell Biol 2005; 170: 1079-90.

100 Dutzler R, Campbell EB, Cadene M, Chait BT, MacKinnon R. X-ray structure of a $\mathrm{CIC}$ chloride channel at $3.0 \mathrm{~A}$ reveals the molecular basis of anion selectivity. Nature 2002; 415: 287-94.

101 Miller FJ Jr, Filali M, Huss GJ, Stanic B, Chamseddine A, Barna TJ, et al. Cytokine activation of nuclear factor kappa $B$ in vascular smooth muscle cells requires signaling endosomes containing Nox1 and CIC3. Circ Res 2007; 101: 663-71. 